\title{
The clinical burden of microscopically patent and sub-microscopic $P$. falciparum and $P$. vivax malaria in pregnancy in Indonesia
}

\author{
Rukhsana Ahmed ${ }^{1 *}$, Puji PB Asih² ${ }^{2}$ Rintis Noviyanti ${ }^{2}$, Ismail EP Rozy ${ }^{2}$, Leily Triyanti ${ }^{2}$, Rita Marleta ${ }^{3}$, Feiko ter Kuile ${ }^{1}$, \\ Din Syafruddin ${ }^{2}$
}

From Challanges in malaria research: Core science and innovation

Oxford, UK. 22-24 September 2014

\section{Background}

Malaria in pregnancy poses a major public health problem in Indonesia with an estimated 6 million pregnancies at risk of $P$. falciparum or $P$. vivax malaria annually. The association between microscopically patent and PCR positive sub-microscopic malaria with maternal anaemia and low birth weight babies was assessed in South-west Sumba and Jayapura district, Papua, Indonesia.

\section{Materials and methods}

Cross sectional surveys were conducted between June 2008-May 2009 in antenatal women and at delivery including home deliveries in SW Sumba (low-moderate transmission) and Jayapura (high transmission). Maternal and placental blood samples were obtained at antenatal attendance and at delivery for haemoglobin measurement, smear microscopy and PCR.

\section{Results}

A total of 4230 women (2598 attending antenatal care and 1632 at delivery) were enrolled. The prevalence of maternal parasitaemia detected by microscopy was $7.0 \%$ [(180/2598) (mono-infection with P. falciparum: 58.3\%, with $P$. vivax: $20.6 \%$ and $0.5 \% P$. ovale and $5.6 \%$ mixed infections ( $P$. falciparum $+P$. vivax), and this was $12.3 \%$ by PCR (P. falciparum $58.4 \%, P$. vivax $31.5 \%$, mixed (P. falciparum + P. vivax): $10.1 \%)$ and $10.7 \%$ in Sumba and $14.2 \%$ in Jayapura, respectively. Sub-microscopic parasitaemia (microscopy negative, PCR positive) was detected in $8.3 \%$ women. With patent infections only $P$. falciparum was associated with moderate-severe

'Liverpool School of Tropical Medicine, Pembroke Place, Liverpool, UK Full list of author information is available at the end of the article anaemia $(\mathrm{Hb} \leq 9 \mathrm{~g} / \mathrm{dL}) ;$ [RR 2.2 (95\% CI 1.7-2.9) P. vivax RR 0.5 (0.3-0.9)] whereas with sub-microscopic infections both species were associated with increased risk of moderate to severe anaemia [P. falciparum: RR 2.1 (95\% CI 1.6-2.8) and P. vivax: RR 1.9 (95\% CI 1.3-2.7)]. The prevalence of placental malaria was $4.8 \%(72 / 1632)$ by PCR and 3.3\% sub-microscopically; this was $2.4 \%$ in primigravidae, $3.1 \%$ in secundi and $1.7 \%$ in multigravidae ( $\geq 3$ pregnancies). The mean difference in birth weight in women with patent placental $P$. falciparum infection compared with uninfected women was $101 \mathrm{~g}$ (95\% CI 70-273 g) with RR 2.1 (95\% CI 1.2-3.0) for low birth weight. The reduction in birth weight with sub-microscopic infection was $70 \mathrm{~g}$ (63-204 g) with low birth weight RR 1.7 (95\% CI 1.0-2.5). Corresponding figures for P. vivax were: patent placental infections: $252 \mathrm{~g}$ (57560 g), low birth weight RR 4.7 (95\% CI 2.2-67); and for sub-microscopic infections the mean difference in birth weight was 146 (70-364 g); low birth weight RR 2.9 (95\% CI 1.6-3.4).

\section{Conclusions}

Sub-microscopic infections are common in eastern Indonesia and are associated with maternal anaemia and marked reductions in birth weight. Strategies that prevent sub-microscopic infections such as intermittent preventing therapy or that which results in their early detection and treatment, such as intermittent screening strategies should now be explored in South-east Asia.

\section{Authors' details}

'Liverpool School of Tropical Medicine, Pembroke Place, Liverpool, UK.

${ }^{2}$ Eijkman Institute for Molecular Biology, Jl Diponegoro 69, Jakarta, Indonesia. 
Published: 22 September 2014

doi:10.1186/1475-2875-13-S1-P2

Cite this article as: Ahmed et al.: The clinical burden of microscopically patent and sub-microscopic $P$. falciparum and $P$. vivax malaria in pregnancy in Indonesia. Malaria Journal 2014 13(Suppl 1):P2.

Submit your next manuscript to BioMed Central and take full advantage of:

- Convenient online submission

- Thorough peer review

- No space constraints or color figure charges

- Immediate publication on acceptance

- Inclusion in PubMed, CAS, Scopus and Google Scholar

- Research which is freely available for redistribution

Submit your manuscript at www.biomedcentral.com/submit
() Biomed Central 